\title{
IDEALISM AND REALISM IN THE POST-WAR FOREIGN POLICY DEBATE IN JAPAN $*$
}

\author{
Sakai Tetsuya**
}

\section{INTRODUCTION}

In the post-Second World War discourse on foreign policy, the most frequently used style of debate was the juxtaposing of idealism and realism and pitting them one against the other. The two opposing positions also characterized the debate on Japan's foreign policy - idealism rooted in pacifism as espoused by the post-war Constitution, and realism drawing upon arguments within the context of the US-Japan Security Treaty. The controversy was engendered by the Cold War and the peace treaty debate, and intensified during the discussion on constitutional reform in the late 1950s. ${ }^{1}$

\footnotetext{
This paper was first published in Japanese in the March 1996 issue of Kokusai mondai [International Affairs], journal of the Japanese Institute of International Affairs [Nihon Kokusai Mondai Kenkyujo]. It has been translated for publication in this Yearbook under a programme of the Foundation for the Development of International Law in Asia (DILA) for the translation of papers of outstanding interest and quality which are originally written in an Asian language. The General Editors of the Yearbook welcome proposals for translation under this programme.

** Professor of International History, University of Tokyo.

1 After the conclusion of the San Francisco Treaty, political conflict broke out in Japan between the opposition partiesthat, drawing upon the war-renouncing provision of Article 9 of the Japanese Constitution, espoused pacifism, and the conservative parties which dismissed pacifism as unrealistic and attempted to promote foreign policies in line with the US-Japan Security Treaty. The conservative camp attempted to revise Article 9 of the Constitution, but met strong resistance from the opposition parties and the intellectuals. The move to revise and renew the US-Japan Security Treaty by the cabinet of prime minister Nobusuke Kishi in 1960 triggered a massive resistance movement. Kishi's background as a central figure in the pro-constitution revision movement and having been a defendant in the Tokyo Trial for war criminals particularly excited the opposition. Kishi's move was thus perceived as a threat to democracy. His cabinet managed to renew the treaty but was forced to step down immediately after. After this incident, the conservatives gave up on upholding constitutional revision as one of their banner policies, but the conservative-progressive conflict left a lasting impact on Japan's foreign policy debate. The post-war debate on Japan's foreign policy came to be characterized as the conflict between the idealists-progressives, and the realists-conservatives.
}

Asian Yearbook of International Law, Volume 9 (B.S. Chimni et al., eds.)

(C) 2004 Koninklijke Brill NV. Printed in The Netherlands, pp. 79-95. 
Although the security treaty issue of the 1960s led the conservatives practically to give up their call for constitutional revision, the confrontation between the two positions deepened and was further intensified by the realists with their arguments, which were derived from the realist theory of international relations in the United States. Irrespective of the specific positions taken, the idealist-realist dichotomy came to serve as the parameter of the debate on post-war Japanese foreign policy. ${ }^{2}$

Without doubt this pattern of debate closely reflected actual political processes and the corresponding political positions of the discussants. The surprising thing is that attempts to examine thoroughly the controversy in a broader context of political thought theory have been sorely lacking. Paradoxically, this may prove that the participants in the debate shared a common understanding to the effect that the debate was in fact predicated upon a peculiar set of premises and circumstances.

Should we look at the ideas developed by the Japanese post-war foreign policy theorists as an isolated product of thinking, secluded from developments in other parts of the world, or were they inspired and influenced by contemporary theories of foreign policy elsewhere? If they were, what then was the exact influence, and what was that intellectual legacy? The pursuit of these issues seems an indispensable exercise when we discuss the intellectual basis of the post-war foreign policy debate in Japan and reflect on the philosophical bases of that policy.

Against this background, the following chapters will examine the course of the Japanese debate on foreign policy with due attention to its intellectual background. First, a review is given of the theories on international politics in the inter-war period in order to determine the basic elements of the idealist and realist schools. This will be followed by a discussion of how the post-war debate absorbed and adopted, and further developed, these inter-war theories.

\section{THE INTER-WAR PERIOD AS THE SEMINAL YEARS FOR THE IDEALIST AND REALIST MODELS OF POLITICAL THOUGHT}

A fundamental distinction between the various political theories is based on a different understanding of human nature, and the idealist-realist dichotomy reflects this difference. The idealist school tends to start from the innate goodness of human nature, asserting that human beings strive towards perfection by drawing upon their inborn sociability and through enlightenment.

\footnotetext{
${ }^{2}$ For an exploration of the lines of thought behind Japanese foreign policy since the Meiji Restoration in terms of conflict between government realism and opposition idealism, see Iriye Akira, Nihon no gaiko [Japan's foreign policy] (Chuo Koron-sha, 1966). For an overview of the post-war foreign policy debate cf., inter alia, Shin'ichi Kitaoka, "Sengo nihon no gaiko shiso" [Thoughts on post-war Japanese foreign policy], in Shin'ichi Kitaoka (ed.), Sengo nihon gaikoron-shu [Essays on post-war Japanese foreign policy] (Chuo Koron-sha, 1995).
} 
The realist school, on the other hand, leans towards the idea that human nature is fundamentally bad, stressing as they do the ubiquitous human desire to dominate and to hold power. From this perspective, the idealist-realist antithesis has been an ever-present component of the political theory debate, reflecting different perceptions of human nature. One could argue that as such the conflict is of an a-historical nature. ${ }^{3}$

In order to determine the place of the idealist and realist positions in the history of political thought of the twentieth century it is necessary to review the discourse of the inter-war period. It was from this discourse that the basic pattern of the debate emerged. It is to be noted, in addition, that the experience of the First World War in fact deprived the Western state system of its most typical feature: the principle of the balance of power that up to that time had served as the fundament of international politics.

Emerging around the end of the First World War, Wilsonianism and Leninism contributed to an increasing weight of ideology as a component of international politics, and thus accelerated changes in the latter's structure. At the same time, they gave a boost to the anti-imperialist movement in nonWestern countries which hoisted the slogan of national self-determination. Evidently, these changes had their impact on the theory of international politics. The prevalent studies on diplomatic history and traditional international law in the time prior to World War I were premised on a society of sovereign nation states. This gave way to a newly dominant universalist doctrine of international politics and law, inspired by newly established international organizations. Idealism thus emerged by way of theory with its birth closely related to the appearance of the post-war universalist views.

After the war the new debate spilt over into Japan. The theory of international politics espoused by Sakuzo Yoshino, an ideologue of Taisho democracy, ${ }^{4}$ serves as a chief example. ${ }^{5}$ He applied the "free and equal" principle, hitherto known only among individuals, to international relations, thus attributing a new characteristic to international politics. Yoshino called the change a transition from "Imperialism" to "International Democracy".

The approach to peace-making also underwent a change as it evolved from that focusing on the adjustment of interests among belligerent states to the kind proposed by the United States and the Soviet Union: peace settlement based on abstract principles such as non-assimilation, non-compensation, and

\footnotetext{
3 For a historical background of idealism and realism, see David Long and Peter Wilson (eds.), Thinkers of twenty years' crisis: inter-war idealism reassessed (Oxford, 1995); Michael Joseph Smith, Realist thought from Weber to Kissinger (Louisiana State U.P., 1986)

4 Taisho Democracy is a term that refers generally to the democratic movement that emerged during the pre-WWII period. The period in which this movement occurred generally corresponds to the era in which Emperor Taisho reigned (1912-1926), hence the name of the movement.

5 Sakai Tetsuya,"Yoshino Sakuzo no kokusai minshushugi-ron" [Yoshino Sakuzo's theory on international democracy], in Yoshino Sakuzo senshuu, dai-rokkan kaisetsu [Selected works of Yoshino Sakuzo] Vol.6 (Iwanami Shoten, 1996)
} 
self-determination. It was a harbinger of the trend to come, one in which postwar international relations would be built upon universal principles of freedom and equality.

From this angle, Yoshino attempted to demonstrate the imperative nature of Minponshugi, his rendition of democracy, ${ }^{6}$ and called for the fulfilment by Japan of the various requirements of international democracy. This understanding of international politics provided the soil in which Yoshino's support of the Washington regime ${ }^{7}$ and his deep sympathy towards Chinese nationalism had their roots. In assessing Yoshino's argumentation it is interesting to know that he was heavily influenced by the legalist peace theory that was prevailing in the Anglo-American countries. From the perspective of international justice Yoshino assigned significance to the League of Nations because of its international law enforcement mechanism. The idea of such an organization had up to that time been heard only as thefeeble cries of small states. The increasing mutual dependence in the international society had gradually placed its constituent members under a common norm. That, in turn, meant that an integrated system of sanctions would penetrate the international society, as had been the case in the domestic society. It was the evolution of the community of international law that caused the League of Nations to become the realization of a body that would ensure international sanction. Previously, Yoshino had seen the US's participation in the war against Germany as a form of execution of international sanction, and strongly endorsed it.

In later years Yoshino retreated from commenting on contemporary issues and turned to what is known as "Meiji Bunka Kenkyu", or studies of the history, politics and culture of the Meiji period. Yet, his interest in theories of international politics persisted. In "Emergence of political awareness in modern Japanese history", ${ }^{8}$ the culmination of his studies on Meiji-period history, Yoshino addressed the concept of "Kodo" or the formulation of a perception of universalist normativity. It is easy to recognize that the thesis, which characteristically discussed Japan's adoption of universal public international law around the end of the Edo period, is in line with Yoshino's postwar interest in international law to which he was converted.

\footnotetext{
${ }^{6}$ Minponshugi was a translation for "democracy" and was adopted by intellectuals in the pre-war period such as Yoshino Sakuzo. The word signified that politics is to reflect people's will but it conveniently obscured the question of where sovereignty lies. It thus permitted the user of the term to deflect the potential dilemma between the emperor system and democracy. In order to promote democracy in the Japanese political context, Yoshino and others used this term as an equivalent of the word democracy.

7 The international framework for peace and security in the Asia-Pacific region that comprised several international treaties concluded at conferences held in Washington from 1921 to 1922 . They included the Four Power Pact on the security of the pacific, Five Power Treaty on naval arms reduction and Nine Power Treaty on territorial integrity and the open door commercial status of China.

8 Op. cit., n. 5, Vol.11: Yoshino Sakuzo senshuu daijyuuikkan (1995) 223-290.
} 
The occurrence of the Manchurian Incident posed a clear challenge to the universalist approach of international relations had put forth by Yoshino as a foundation of Taisho democracy. The Manchurian crisis and the subsequent departure of Japan from the League of Nations exposed the flaw of the collective security system as applied by a universal international organization. The Japanese government justified the actions of the local military forces as an act of self-defence. It structured its legal argument in such a way as to avert the application of the Kellogg-Briand Pact and yet to maintain consistency with the existing international legal framework. These efforts, however, were merely an attempt to disguise the real events.

Yokota Kisaburo was one of the few other Japanese intellectuals who were overtly critical of the Manchurian Incident. He was a normativist international legal scholar under the influence of Hans Kelsen's teachings. The Manchurian Incident had, of course, a wrenching impact on the existing international legal order. With the universalist approach smarting under itseffects, the Japanese intellectuals were faced with the task of presenting an alternative view on international relations. They found that alternative in a regional variety of the international order. The idea of a system of generally applicable international norms premised on a society of sovereign states, as was the case in the West, was not adequate in East Asia, where nation states were still at an early stage of development. Therefore, a special international system for Asia was in order. Initially, the argument averted a direct clash with the prevailing international order by treating the Asian situation after the Manchurian Incident as an exceptional development. As the Sino-Japanese War dragged on, however, the Japanese ideas developed into a critique in principle of the existing international order as epitomized by the Nine-Power Treaty.

The result was a theory on a new order for the Greater East Asia region. On the one hand it manifested as a regionalist theory, influenced by the "Grossraum" - extensive space - principle, and critical of both universal international organization and the idea of an atomistic co-existence of individual states. On the other hand, it was posited as an alternative to overcome the existing order dominated by the imperialist Anglo-American powers.

The theory even captured the attention of some Marxists. ${ }^{9}$ These aspects mirrored the distorted reaction of the Japanese intellectuals to the post-war universalist view of international relations. It is generally held that the policymakers grew increasingly ideologist in the 1930s, in contradistinction to their previous, mainly realist, approach to foreign policy. ${ }^{10}$ The ideological twist, paradoxically, underscored the significance of the challenge of both Wilsonianism and Leninism as faced by the Japanese policy makers and intellectuals.

\footnotetext{
9 On the rise of the regionalist view after the Manchurian affair, see Mitani Taichiro, "Kokusai kankyo no hendo to nihon no chishikijin" [Tectonic shift in the international milieu and the Japanese intellectuals], in Taisho demokurashii-ron [Taisho democracy] (old edn., Chuo Koron-sha, 1974) ${ }^{10}$ Iriye, op. cit., n. 2 at 135.
} 
The increasing role of ideology was thus a product of the prevailing intellectual mood in the world after the first World War when the Western state system had lost its self-evidence.

It follows from the foregoing that the criticism of the universalist theory of international politics by Japanese intellectuals crystallized into a regionalist theory. However, that was not a matter of necessity, since criticism of universalism could burst and branch into a variety of theories. In fact, the realist theory dominating the post-World War II international discourse also had its seeds in the inter-war debate.

Hans Morgenthau, known as the progenitor of realist international political thought, was a student of international law before he sought asylum in the United States. He was academically educated in German political science or "Staatslehre" of the inter-war period, in an atmosphere of anti-Kelsenism. Morgenthau's first-born book, Die internationale Rechtspflege, ihr Wesen und ihre Grenzen [The international administration of justice, its nature and its limits $]^{11}$ which was published in 1929 , examined the question of the exclusion of political disputes from international adjudication, meticulously drawing on legal theoretical considerations. The book purported to subject the normative school of international law, which advocated the realization of international peace by referring all international disputes to judicial settlement, to an immanent criticism.

Morgenthau then proceeded to examine the legal philosophy of the NeoKantians which provided the epistemological basis for the pure theory of law advocated by Kelsen. He explored, inter alia, the reality of norms. The book of that title, ${ }^{12}$ published five years after the publication of his first book, questioned the reality of the legal norm, an issue that was left outside the scope of the pure theory of law. He analyzed both the relationship between legal norms and other customary and moral norms, and that between legal norms and non-normative social forces. The book, which has a highly complex structure, can hardly be considered a masterpiece. Nonetheless, it clearly affirms Morgenthau's interest in exploring a methodology for the establishment of a functionalist international law. This is done by questioning the reality of norms while being inspired by Kelsen's endeavour to establish a unified perception of legal phenomena.

Morgenthau was concerned, at a basic intellectual level, with the reconsideration and the reconstruction of the normative structure of international society by making the actual basis of the legal norm, previously left out of the pure theory of law, the very object of his study. In so doing, he introduced into the realm of international law the methods of the more political versions

11 Leipzig, 1929.

${ }^{12}$ La réalité des normes, en particulier des normes du droit international [The reality of norms, particularly the norms of international law] (Paris, 1934). Under the influence of Kelsen, see ibid. at $1-9$. 
of government studies, as developed by Carl Schmitt and Hermann Heller during the Weimar Republic era.

After his emigration to the United States, Morgenthau's theory of international politics was further stripped of its legalist component as he ushered in a sociological construction revolving around the concept of power politics. Morgenthau's change in methodology stemmed from his involvement in a debate on the legalist world government theory, which had deep-rooted proponents in the US academic world. One can easily identify Morgenthau's concerns when reading his texts with his intellectual legacy in mind. His leading work, Politics among nations, ${ }^{13}$ most clearly illuminates this point. The book's opening assertion, that power relations are omnipresent, often leads readers to draw the conclusion that the book in fact purports to argue the imperative nature of Hobbesian anarchism and power politics in international society. However, in view of the pattern and history of Morgenthau's intellectual development one could well argue that the book was not really written in the order of chapters as composed.

Morgenthau's earlier thoughts correspond with (the often overlooked) Chapters 13 and 16 of his book, on "Ethics, mores, and law as restraints on power", and "The main problems of international law" respectively. His theoretical endeavours had begun with questions on the reality of norms of international law as treated in these chapters. His analysis of norms and nonnormative social forces then expanded into his famous analysis on power politics. With these sociological analyses at hand, Morgenthau proceeded to the question of how the community of international law could be developed and promoted.

Contrary to his real inclination Morgenthau has often been dismissed as a student of Machiavellism. His polemical expressions and style aside, such a mistaken notion appears to have arisen primarily from the fact that American readers, uninformed of Morgenthau's intellectual background in German political science (Staatslehre), somehow failed to appreciate the significance of his Kelsenian dilemma in the evolution of his thoughts on politics.

E.H. Carr encountered the same issues out of a socialist concern the same way as Morgenthau arrived at realist international theory from a conservative interest. Due to his pointed criticism of the utopian peace theory, Carr's Twenty Years' Crisis has been given a place in academe as a classic on realist theory. Nevertheless, as in the case of Morgenthau, it appears that relatively few efforts have been made immanently to analyze the intellectual context from which Carr's international theory emerged and to assess what kind of sense of history it involved. To put it plainly, Carr's theory is a projection of his criticism of laissez-faire principles onto the international plane from a socialist standpoint.

13 New York, 1948. 
Carr's image of Wilsonianism might be termed "belated Benthamism". $\mathrm{He}$ argued that the distinguishing characteristic of Wilsonianism lies in Wilson's application of the myth of the laissez-faire principle and the selfadjusting nature of economic interests, a dilemma Carr believed was being overcome in post-war Europe, to the arena of international politics which had until then been relatively free from the application of the liberal concepts. Carr cited, quite symbolically, as the most proximate example of peaceful change in international society, the institutionalization of the labour-management cooperative framework. ${ }^{14}$

It must be remembered that Carr's realism was inseparably linked to his ideological criticism of the international order led by the "have" nations in both methodology and subject. How does Carr lay out the path to his version of socialism in his international theory? Characteristically, Carr demonstrated a strong interest in the impact of social change brought about by a total war. The experience of a controlled economy introduced during the First World War inevitably caused modification of the laissez-faire ideal. However, the post-war world order designed by Britain and the United States was a conservative one intended to impede an immutable process, Carr argued. It was the Soviet Union and the later Axis powers rather that proposed an alternative to the stalled order based on the classical liberal doctrine. The fascination of the alternative order in the context of the turbulent 1930s lay in this key respect. How the West responded to the proposed "new order" envisaged by the Axis powers and the Soviet Union would help determine the tide of the second World War. To answer them properly, it was imperative for the West to present a framework to accommodate the social changes brought about by the war.

Carr proposed that the wartime planned economy and full-employment be maintained after the war. Accordingly he argued against reversion to the gold standard and the free trade system; rather, the establishment of a new economic regime was imperative, one that was based on regional economic cooperation cutting through the boundaries of the nation states. ${ }^{15}$ In Twenty Years' Crisis Carr stressed the complementary nature of realism and utopianism, and he did not mean it in a merely abstract sense. Carr's version of utopia envisioned the construction of socialism based on a wartime planned economy and regionalism, this being the other side of the coin of his realist criticism of the liberal order that was by that time in ruins.

Morgenthau and Carr closely shared their criticism of the idealist international theory of the 1920s that was buttressed by the emergence of universal international organizations, but differed markedly in their underlying concerns

${ }^{14}$ E.H. Carr, Twenty Years' Crisis (Jap. transl. by Inoue Shigeru, Iwanami Shoten, 1952, at 279-282).

${ }^{15}$ For Carr's views on total war and the post-war design, see E.H. Carr, Conditions of peace (New York, 1943). See also Mitani Taichiro, "The war-time regime and the post-war regime", in Iwanami Koza: Kindai nihon to shokuminchi, daihakkan [Iwanami lecture series: Modern Japan and its colonies, Vol.8] (Iwanami Shoten, 1993) at 315-318. 
and values. Consequently, the two thinkers are by no means identical. Remarkably, however, their concerns correspond very closely to those of contemporary Japanese scholars. This becomes obvious when their intellectual contexts are compared and examined.

Carr's interest in the wartime-planned economy fundamentally coincides with the arguments put forth by Ohkohchi Kazuo who defended the planned economy of the Sino-Japanese War on social policy grounds. Besides, the ideological criticism of the international order of the 1920s and its characterization as Anglo-American-centric pacifism was most congenial to the thinking of Japanese intellectuals during the Sino-Japanese war. At the same time, Morgenthau's scholarly work had captured the attention of up and coming Japanese international law scholars as a new academic development, indicative of the arrival of the post-Kelsenian era. ${ }^{16}$

With the normative approach of international law facing a major crisis in the 1930s, Morgenthau's functionalist approach appealed strongly to those in search of a new model. There are aspects of Morgenthau's and Carr's theories that share a common intellectual ground with Japanese theories of the 1930s in that neo-Kantianism, which had served as a philosophical foundation for the Taisho democracy, had come under attack as the social and political reality of norms were called into question. Proponents of the attack leveraged arguments of Karl Marx and Carl Schmitt. In this key respect, the Japanese intellectual world proved a fertile ground for the realist international theory, as was the Western world. We shall now see how this intellectual heritage was passed on to the foreign policy debate in the post-war world.

\section{FORMULATION OF THE POST-WAR FOREIGN POLICY DISCOURSE}

After the Second World War, the leading intellectual agenda of the Japanese scholars was the construction of a post-war constitutional regime. As

\footnotetext{
${ }^{16}$ See Tabata Shigejiro, "Kokusai saiban ni okeru seijiteki funso no jogai ni tsuite: Sono genjitsuteki imi no kosatsu" [On the exclusion of political disputes from international adjudication: assessment of its realistic implications], in Hogaku ronso, Vol.33, No.5 (1935) 114-123; Yasui Kaoru, "Kokusai hogaku ni okeru jisshoshugi to kinoshugi - Mogenso no kokusaihogaku hohoron no kento" [Positivism and functionalism in international law: examination of Morgenthau's methodology in international law], in Hogaku Kyokai zasshi, Vol.61 (1943), No.2.5, later republished in Yasui Kaoru, Kokusai hogaku to bensho-ho [Studies of international law and its dialectic] (Hosei U.P., 1970). On a postSecond World War reflection on Morgenthau, see Tabata Shigejiro, Kokusai shakai no atarashii nagare no nakade - Ichi kokusaihogakuto no kiseki [In the new current of international society: the footsteps of an international legal scholar] (Toshindo, 1988) at 23.
} 
already pointed out in previous studies ${ }^{17}$ the arguments rolled out repeated parts of the political and economic debates of the war period. The concept of a "cultural state" [bunka kokka ron], put forth by Watsuji tetsuro and Abe Yoshishige, was an attempt to lend legitimacy to the post-war system of a symbolic emperor while carrying on the notion of "national community" [kokumin kyodotai-ron] envisioned during the war. ${ }^{18}$ On the other hand, leftwing intellectuals shared extensively the idea that the very experience of the war-time planned economy would serve as the foundation of the post-war economic reconstruction. Initiatives for post-war economic revival, including the priority production system introduced by the Katayama Tetsu government, were without doubt the result of that school of thought. ${ }^{19}$ The disintegration of the Japanese intellectual world of the immediate post-war years into a conservative and a socialist camp as a result of various social upheavals resulted in each of the camps in fact inheriting each of the two opposing positions that had already existed under the Konoe government during the war. $^{20}$

The burgeoning constitutional debate focused on two issues: the status of the emperor, and the socio-economic problems, reflecting the concerns of the intellectuals of the time. What theories did these intellectuals propound in the course of the drafting of the constitution? Contrary to what one might expect, there were few commentaries on international politics or peace theories at the time, perhaps reflecting the conditions prevailing under the US occupation. However, Yokota Kisaburo constituted an exception.

\footnotetext{
17 Yonetani Masafumi, "Shocho tenno-sei no shisoteki kosatsu" [Examination of the ideas concerning the symbolic emperor system], in Jokyo, Dec.1990; Mitani Taichiro, "Sengo nihon ni okeru yato ideorogii toshiteno jiyuushugi" [Liberalism as the ideology of the opposition forces in post-war Japan], in Indo Kazuo, Yamaguchi Yasushi, Baba Yasuo and Takahashi Susumu (eds.), Sengo demokurashii no seiritsu [Establishment of post-war democracy] (Iwanami Shoten, 1988)

${ }^{18}$ The cultural state argument sought the foundation for a nation state in the commonality of culture and is one of the leading state theories in modern Germany. Many Japanese intellectuals discussed how nation states ought to be formed with this concept in mind. It differed from the individualistic state theory in that it saw cultural identity as the foundation for nation states. And it shared much in common with the national community theory which saw the nation state as one organic community. After the war, philosophers Watsuji Tetsuro and ABE Yoshishige positioned the emperor as the symbol of Japan's cultural identity and attempted to defend the emperor system by marking a contrast between the "cultural state" based on the symbolic emperor and the pre-war militarism.

19 Economic policy aimed at promoting Japan's post-war economic reconstruction. It attempted to raise productivity by allocating goods, labor and capital to priority industries. The policy was adopted by the cabinet of Katayama Tetsu, who was the president of the Socialist Party, to overcome the economic crisis of the post-war Japan.

${ }^{20}$ During the Sino-Japanese War under the cabinet of Konoe Fumimaro, "unity of the people" was stressed to carry out the war effectively. But the definition of unity varied among discussants. Many leftist intellectuals saw an opportunity to bring socialization to Japan in the planned economy implemented under an all-out war and attempted to restrain the profit motives of the industrialists under the name of public interest. Intellectuals from the conservative camp on the other hand were cautious of these leftists' moves.
} 
Yokota perceived the new constitutional provision on the renunciation of war as part of the tendency, already existing since the first World War, toward characterizing war as unlawful, and endorsed it in the context of a collective security system, which he had been advocating. He purported to demonstrate that the pacifism as envisioned in the new constitution was brought on by "the revolution of international law". Yokota, whose criticism of the Manchurian incident had left him a minute minority in the world of opinion makers, thus saw his reputation restored after the war. The international theory to which he resorted closely resembled the idealist theory on world government as put forth by Emery Reves in The Anatomy of Peace.$^{21}$ Idealist theories such as this occupied a legitimate place in Japanese academia in the immediate post-war years. Yet Yokota's theory seems to have left a trace of awkward feeling among contemporary scholars, although this was not directly articulated at the time.

The school of thought that actually interceded between the pre-war and post-war theories came from the other side of the line in the dual intellectual heritage. The arguments of Tabata Shigejiro who took a critical stance towards Yokota's normative view of international law is one manifestation of this development. Tabata's Kokka byodo kan-nen no tenkan [Conversion of the concept of equality of states], ${ }^{22}$ published in 1946, is a classic on the history of international law written under the suppression of sentiments during the war, and is rich with suggestions for the reconstruction of an international society according to post-war standards. Tabata traced the development of the concept of equality of states in international law, and thereby called into question the prevailing view that Hugo Grotius established the basic principles of modern international law. He argued that Grotius' universalism is founded on an Aristotelian-scholastic view of man, which presupposes man to be born sociable. He also argued that Grotius' natural law theory, which postulates objective and transcendental norms with validity in and of itself, beyond man's and God's wisdom, is redolent of medieval residue. It should be noted that Tabata's qualification of Grotius as being "pre-modern" connotes his criticism of the post-World War I resurgence of Grotius by the universalist school of international law.

Instead of Grotius, Tabata credits and praises Samuel von Pufendorf for having spawned modern concepts of international law. The concept of the equality of states was born when Pufendorf applied, by analogy, the concept of equality among men in their natural state to the international society. As did Hobbes, Pufendorf conceived the atomist structure of the international society consisting of personified, individual, states, following the disintegration

21 Yokota Kisaburo, Sekai kokka no mondai [Problems of world government] (Dobunsha, 1948) at 13. For Yokota's peace theory immediately after the war, see Takenaka Yoshihiko, Nihon seijishi no nakano chishiki-jin, gekan [Intellectuals in Japanese political history, Vol.2] (Bokutakusha, 1995) 501-526.

22 Akitaya, 1946 
of medieval universal society. However, unlike Hobbes, Pufendorf's version of the natural state theory is not one in which individuals, driven by the impulse of self-preservation, are engaged in a constant struggle with one another. Pufendorf's recognition of the natural equality of men entails normative duties - such as "thou shalt not hurt others". It is not like the Hobbesian idea that presupposes equal power among individuals.

Thus Pufendorf's view of state equality presupposes both recognition of the natural freedom of individuals, and duties arising from natural law. However, these do not necessarily match with each other. In fact, the delicate balance between freedom and duty, maintained by the optimism of the enlightenment era, collapsed, and as international law took an increasingly positive form, the concept of state equality began to converge into what was in fact a "nominal" equality of states which mostly just spelled out their liberty and independence.

Tabata ascribes this dilution to the failure of the natural law theory to provide a framework capable of capturing the dynamism of the international society. This failure materialized as the theory, during the enlightenment period, wrongly presented the international society in an abstract way, calling it "states in general", which was a most unhistorical and unsocial proposition. Tabata here reveals his long-standing intellectual trait of valuing the social and historical significance of the norm. Yet, Tabata did not rule out all aspects of the natural law-based concept of state equality. After publishing his abovementioned book, Tabata expanded his horizon of study and proposed to reevaluate the merits of Emmerich de Vattel, who had been criticized for the arguments advanced in the founding of an atomist theory of international law, including the principle of absolute sovereignty for individual states. Tabata contended that branding de Vattel as the chief advocate of the theory of absolute sovereignty allowing no superior norm over individual states would be tantamount to projecting the image of a post-Hegel Staatslehre upon him. With de Vattel sovereignty had a progressive meaning. He in fact emphasized that the states' autonomy vis à vis other states shields them from interference by absolutist states which would hamper the formation of nation-states based on the sovereign rights of the people. De Vattel did not argue in favour of sovereignty for sovereignty's sake. Exercise of sovereignty is allowed so far as it does not hurt the rights of other nations, and abuse was thus strictly forbidden. Depending on the sovereignty holder's qualities the concept can play a progressive role against the abusive dominance of a super-power even today. $^{23}$

Tabata's arguments are well disciplined academically, making his views all the more interesting if we approach them, and other theories like his, from the perspective of the way of thinking of their authors. On the basis of his criticism of the abstract norm for its ignoring of the reality of international

23 Tabata Shigejiro, Kokka shuken to kokusaiho [State sovereignty and international law] (Nihonhyoronshinsha, 1950) 24-33. 
society, Tabata reveals a strong scepticism towards the universalist international view. This scepticism found expression in an argument re-assessing the efficacy of the concept of sovereignty and in a counter-argument against universalism. It shows that Tabata follows the inter-war criticism of universalism and thus coincides with the realist international theory in content and heritage.

Another significant point is that the revival of the concept of sovereignty is also linked to the concerns of a civil society by way of the "bearer-of sovereignty" argument. There would indeed be a big difference between reevaluating de Vattel and classifying him as the initiator of the concept of indiscriminate war, on the one hand, and positioning him as the international legal theorist basing himself on the theory of people's sovereignty on the other. The post-World War II interest in democracy was thus linked to the revival of the sovereignty concept. Finally, the sovereignty concept was also taken as an argument against the dominance of the super-powers and thus as a device for the promotion of solidarity with the Asian and African countries that were seeking de-colonization.

Tabata's way of posing questions such as his proposing the re-evaluation of the substantive equality of states, at a time when the atomist theory of international relations was under pressure of the war-time idea of a Greater East Asia Co-prosperity Sphere, undoubtedly contained an element of criticism of regionalism as an important tool of super-powers. It should be noted that the device was also congenial to the Marxist-inspired anti-imperialism. In fact, the concept of international law for the transitional period as proposed by the Soviet school of international law in the inter-war period, which is linked to the name of Pashukanis, aimed at resuscitating the concept of sovereignty in the face of the overwhelming tide of Western scholarship in international law at the time. ${ }^{24}$

At the time when Yokota dominated the peace theory debate in the immediate post-war years many intellectuals happened to be quite susceptible to this approach of Tabata, and the worsening of the Cold War further revealed this latent conflict. Earlier, Yokota had already propounded the notion that the intensifying US-Soviet conflict made it impossible to forge amicable relationships with China and the Soviet Union. He criticized the idea of a comprehensive peace treaty with the Allied Powers that included the socialist states. When the Korean War broke out he showed his unwavering support for the United Nations sanctions against the Democratic People's Republic of Korea, drawing on his conventional argument of a collective security

\footnotetext{
24 See Yasui Kaoru, "Marukusu-shugi kokusaihogaku no joron: Korovin no Katokikokusaiho no kento" [Introduction to Marxist international law theory: examination of Korovin's Transitional International Law], in Hogaku Kyokai zasshi [Journalof the Jurisprudence Association of the University of Tokyo] Vol.51 (1993), No.4, republished in Kokusai hogaku to bensho-ho [Studies of international law and its dialectic], op. cit., n. 16.
} 
system, and he denounced the neutralism implied in the comprehensive peace proposal. $^{25}$

As the Cold War intensified, the initiative in the peace debate began to shift to Yokota's critics. The publication of Tabata's article "The legal basis of the Tokyo trial" in the June 1949 issue of the journal Sekai was somewhat emblematic of this development. Heiwa mondai danwa-kai [Discussion Circle for Peace Problems], the leading group in favour of a comprehensive peace treaty, comprised a wide range of intellectuals from different generations, and could, therefore, not easily be generalized as belonging to one specific faction. It could be surmised that scepticism towards Yokota and his collective security concept had permeated the atmosphere among the leading members of the Circle. The well-known statement issued by the Circle in December 1950 , entitled "On peace for the third time", could not be understood fully with all its nuances without knowledge of its intellectual background. Written by political scientist Maruyama Masao, constitutional scholar Ukai Nobushige, and economist Tsuru Shigeto, the statement reveals different tones and emphases in different sections, reflecting the diverse concerns and areas of specialization of the authors. One aspect, however, deserves notice in the present context. ${ }^{26}$

The best-known section of the statement, written by Maruyama, connoted criticism of Yokota's collective security theory. The sense of crisis permeating Maruyama's argument was the fear that the United Nations' involvement in a regional military conflict might escalate into sanctions against a major power and ultimately lead to the outbreak of a Third World War. ${ }^{27}$ Maruyama's instinctive rejection of the argument to limit the right of veto and to let the majority principle function mechanically ${ }^{28}$ has as its background his concern that the United Nations might function as an anti-communist crusade led by the General Assembly, as happened in the case of the "Uniting for Peace" resolution. Maruyama pointed out the fundamental problem of the linkage between the collective security system and the idea of just war. The intensification of the Cold War prompted the integration of the following movements: anti-universalism, the civil society argument, and anti-imperialism,

\footnotetext{
25 Takenaka, op. cit., n. 21 at 567-594.

26 When conclusion of the peace treaty rose to the top of the agenda, part of the opposition camp and intellectuals opposed the government position of signing a treaty that excludes the socialist states. They demanded that the peace treaty be a comprehensive one that includes countries like the Soviet Union and the People's Republic of China. Of this opposition movement, Heiwa mondai danwa- kai was a gathering of intellectuals representing a wide range of professions united under calls for a comprehensive peace treaty. The statement the group issued, "On Peace for the third time," elaborated on the need and the significance to maintain peace amid intensifying East-West conflict and has been widely acclaimed and respected as a manifesto of peace theory in Japan.

27 Maruyama Masao, "Sanfuranshisuko kowa, Chosen senso, Rokujyuu-nen anpo"'[The San Francisco peace treaty, the Korean War and the 1960 security treaty], in Sekai (Nov. 1995) 38-41.

28 "On peace for the third time", statement of the Discussion Circle for Peace Problems, in Sekai (Dec. 1950) 38.
} 
with the idea of sovereignty, buttressed by nationalism, acting as a catalyst. The post-war foreign policy discourse was thus born, with the idealistic peace theory that emerged from it in fact springing from the sentiments of a generation who had their youth in the 1930s, the era when the Wilsonian ideals became deeply frustrated.

\section{CONCLUSION}

As the preceding arguments suggest, the conventional portrayal of the post-war foreign policy debate in terms of the dichotomy of idealism and realism can no longer be sustained. The debate in fact resulted from the involvement of elements that are far more complex in composition than had hitherto been contemplated. The significance of it becomes evident when the disputation is examined scrupulously on the basis of its intellectual roots and the reasoning patterns rather than just as a policy controversy. It should thereby be kept in mind that the theory of international politics in post-war Japan has developed from arguments from the inter-war period when Japan was under the strong influence of intellectual movements in Europe, particularly Germany.

The conventional studies ignored these aspects because, being unfamiliar with the inter-war intellectual context, they simply covered up the complexity of the post-war debates by projecting their image of the highly political security treaty dispute of the 1960s back to its formation period immediately after the war. This trend even accelerated after the 1960s when the American school of international politics, as the leader of post-war international studies, shed its philosophical component of the early years and developed into a much simpler form as a positivist theory of international politics.

Because of the European influence referred to earlier, humanist realism, requiring a continental European way of posing the issues and having been transplanted to the US by an exiled intellectual, was more congenial to Japanese intellectuals than were the American approaches, as far as the core intellectual issues were concerned. The arguments of the realists, who made a sensational début into the world of opinion in Japan and who were noted for their introduction of the American approach to the theory of international politics, may in fact have their roots in this intellectual tradition. Both idealism and realism posed the crucial question on the relation between political power and ethics in the 20th century international relations when the system of sovereign nation states lost its self-evidence. To describe the conflict of the two positions as a fruitless debate without regard to their intellectual background is in fact equivalent to the marginalization of both as specific schools of thought.

Both idealism and realism in the inter-war period had a keen awareness of the historical character of the Western state system, the latter even more so than the former in view of its criticism of continental European civilization. 
Both Morgenthau and Carr clearly reveal their sensibility in this respect through their criticism of the nation states. The end of the era of nation states as being at the core of Carr's international theory is visible in his arguments presented during World War II. ${ }^{29}$ The same applies to Morgenthau, who is often regarded as having attributed an absolute character to sovereign nation states. In fact, for a theoretical foundation he relied on an alleged moral bondage of the West that had enabled a sustainable coherence of the Western state system, and as a result he needed to distance himself from the atomist view of the international order. Greater attention should thereby be paid to the negative view of nationalism that pervades his argument throughout. ${ }^{30}$ It should be noted, in passing, that the views of the two scholars later coalesced in devising the concept of a European community. Thus, various modes of criticism of Western civilization in the inter-war period can be seen to have converged into international theory, envisioning a revival of the Western spirit that would lead to the creation of a European community.

Any difference between Japanese and Western scholars would refer to the assessment of nationalism rather than to adherence to power politics among Japanese intellectuals. The difference could be viewed as a topological one with the Western perception of the transition of the Western state system as seen from within, as opposed to the use of the same concepts by Japanese intellectuals in a non-Western society.

Carr's blueprint for a post-war regime reveals a typically Western-centric viewpoint. While admitting that national self-determination after the first World War was unjustly applied to Europe only, he went as far as to express the opinion that cutting the political and military ties between a country like India, lacking the capability for an autonomous existence, and its metropolitan country, would amount to a reactionary measure. ${ }^{31}$ If Carr, being fully conversant with Marxism, could adhere to such a position, it is not surprising that Japanese intellectuals became engrossed in anti-imperialist nationalism in Asia.

The post-war discourse has undeniably been buttressed by this, novel, Asian nationalism. We are facing a rather grim history of the past fifty years filled with issues of nationalism in various forms in Asian countries. Since the disintegration of the imperial order, the construction of a regional order based on a society of equal sovereign states has only just begun. Seen from this perspective, the principle of the equality of states, which has been inter-

29 Twenty Years' Crisis, op. cit., n. 14 at 302-303; Conditions of Peace, op. cit., n. 15 at 39-70. See also his post-war work, such as Nationalism and after (1945).

30 Politics among Nations at 184-196.

31 Op. cit., n. 29 at 68. Carr later cited Joseph Needham, What is History?, as pointing to the new potential of historiography while criticizing the Western-centric bias of British historians. See E.H. Carr, What is history? (transl. into Japanese by Shimizu Ikutaro, 1962, at 227). It could be interpreted as self-criticism. 
nalized by constituent members of the new order, ${ }^{32}$ is now being discussed anew, with the idealist-realist dichotomy as a potential framework of discussion.

2 Tabata, op. cit., n. 22 at 325-328. 